\title{
THE IMPACT OF SELECTED FACTORS ON THE QUALITY OF BUSINESS ENVIRONMENT ASSESSMENT IN THE CZECH REPUBLIC AND THE SLOVAK REPUBLIC
}

\author{
Anna Kotaskova \\ Pan-European University \\ Bratislava, Slovakia \\ e-mail: anna.kotaskova@gmail.com

\section{Zoltan Rozsa} \\ School of Economics and Management in Public Administration \\ Bratislava, Slovakia \\ e-mail: zoltan@,rozsa.sk
}

\begin{abstract}
The paper's aim is to examine the dependence of the quality of the business environment on defined technological factors (availability of human capital and research and development infrastructure) and to define and quantify significant technological factors that create the quality of the business environment in the SMEs segment. Part of its goal was the comparison of the defined factors between the Czech Republic (CR) and the Slovak Republic (SR). In connection with the stated research goal, a questionnaire survey was conducted among businesses operating in the SME segment. Through this research, 312 companies were surveyed in the Czech Republic and 329 companies in the Slovak Republic. To achieve the primary goal of the article, methods such as correlation analysis and multiple linear regression modelling ( $\mathrm{t}$-tests, F-ratio, adjusted coefficient of determination, and so on) were applied. The results of the research have brought interesting findings. Research and development infrastructure, as well as the availability of human capital are important factors that have a positive impact on the business environment in both countries.
\end{abstract}

KEYWORDS: business environment, quality of the business environment, index of quality, technological factors

JEL CLASSIFICATION: O21, G21, M12

DOI: $10.2478 /$ IJEK-2018-0015

Received: $3^{\text {rd }}$ November, 2018

1st Revision: $23^{\text {rd }}$ November, 2018

Accepted: $10^{\text {th }}$ December, 2018

Reference: Kotaskova, A., \& Rozsa, Z. (2018). The impact of selected factors on the quality of business environment assessment in the Czech Republic and the Slovak Republic. International Journal of Entrepreneurial Knowledge, 6(2), 71-80. doi: 10.2478/IJEK-2018-0015

\section{INTRODUCTION}

Small and medium-sized enterprises (SMEs) are an essential part of the economic system of each country, having important effects on the development of the whole society (Dobeš et al., 2017; Ključnikov \& Popesko, 2017; Kozubíková et al., 2017; Virglerova et al., 2016; Czarniewski, 2016; Dubravska et al., 2015; Belas et al., 2015).

This paper explores critical technological factors and their impact on the quality of the business environment in the Czech Republic and Slovakia. We are interested in how the availability and quality of human capital and the support of science and research influence the growth of the quality of the business environment for SMEs.

The structure of the paper is as follows: The theoretical part presents the results of research in the area of quality of the business environment. The next section defines the research goal, methodology, and 
the data used. In the third part, the results of the research are presented along with a brief discussion on the issue. In the final section of the article, the essential conclusions of the research are formulated.

\section{THEORETICAL PART}

The quality of the business environment is of great importance for the competitiveness of the economy as well as for its future and sustainable growth (Korcsmáros et al., 2017, Wruuck, 2015, Chládková, 2015, Bunoa et al., 2015, Fetisovová a kol., 2012).

Several authors examine the factors that determine the quality of the business environment for SMEs. Belas et al. (2018) investigate significant economic risk factors and their impact on the segment of SMEs. Hudáková et al. (2018) pointed to many risks (corruption, clientelism, operational risk, legislation) that may affect the functioning of the company. It focuses more on market risk in the article (Hudáková a kol., 2017). Lazányi et al. (2017) examine whether age, gender, or education have an impact on perceived risk in the context of the quality of the business environment.

According to Buno et al. (2015), the business environment in the firm includes economic, political, institutional, legal, technological, and cultural conditions in which it operates and which form business activities. Similarly, Chládková (2015) states that the business environment is influenced by a wide range of conditions concerning legislation, institutional infrastructure, and market operations.

The complex characteristics of the factors that determine the quality of the business environment are presented by Conorto et al. (2014). Technological factors are factors such as the availability of human capital, research and development infrastructure, public sector cooperation with the private sector, etc.

An interesting issue is the importance of education for SMEs entrepreneurship and specifically the importance of higher education. Several authors address this issue. Irwin and Scott (2010) report that higher entrepreneurship education has a positive impact on the ability to overcome financial difficulties and allows better access to external funding. Higher educated people are more motivated to be entrepreneurs (Velez, 2009; Lafuente, Vaillant, 2013). Well-educated entrepreneurs are more able to perceive opportunities in the market (Naude a kol., 2008), which is closely linked to the higher growth of companies (Rauch, Rijsdijk, 2013, Van der Sluis and Van Praag, 2008). Millian et al. (2014) report that educated entrepreneurs are getting educated employees on the labour market for their business, which has a positive effect on company productivity. Jones et al. (2011) report that entrepreneurial education at a university can positively influence the decision of students to become entrepreneurs. A similar opinion is also provided by Popescu et al. (2016). If universities create a positive environment in their educational activities and support entrepreneurial activities, students are more motivated to start an enterprise (Tredevi, 2016). Quality education in this area significantly increases students' enthusiasm and entrepreneurial skills (Bergmann et al., 2016). Oehler et al. (2015) emphasise that knowledge of finance, accounting, and corporate management is very much needed for students interested in doing business.

In their study, Botlikova and Botlik (2014) attempted to map out from the data of the Czech Statistical Office, their databases and strategic documents on the development of SMEs, and to find a relationship between the development of entrepreneurial activities and the educational structure. The authors were considering factors which would help to create a competitive region that will be able to offer entrepreneurs sufficient conditions for entrepreneurial activities. The research task has highlighted the importance of human capital for the development of the region. The authors emphasise that low business activity in a region associated with a low level of education predetermine the region's position towards a pathological phenomenon such as crime and social exclusion. Finally, the authors declare the fact that the increase in the educational level and the number of educated people in the region demonstrably support the development of SMEs. In their analyses, the authors have shown that the closest relationship is between the development of SMEs and those with secondary education with school-leaving exams and without school-leaving exams. Further development of SMEs is associated with an increase in university-educated people. 
A crucial area that shapes the business environment is the application of scientific and research knowledge to the business activities of SMEs. Several authors address this issue.

The knowledge spill-over theory of entrepreneurship points out the role of knowledge as a source of entrepreneurial opportunities to provoke innovative start-ups (Acs et al., 2009). However, the study conducted by González-Pernía et al. (2015) showed that the different context found in developing economies produces a limited connection between knowledge spill-overs, innovation, and entrepreneurship in comparison with the conventional linkage studied in the literature of this theory. Their findings point out that policy efforts to attract foreign direct investments which are not accompanied by efforts in research and development investment seem to be useless regarding enhancing innovation in developing economies. Policies aimed at improving both knowledge absorptive capacity and the access of entrepreneurs to foreign firms can be beneficial for enhancing innovative business formation in developing countries.

Innovation is an essential factor for a growing firm (Kovalová et al., 2018). Hashi and Krasniqi (2011) researched this relationship, covering data from firms that operate in Central Eastern and South Eastern European countries. The innovation index resulted in the same positive impact in both regions. Furthermore, there were no significant differences regarding the impact of innovation on firm growth in two groups of countries. A similar influence was found for organisational innovation which is positive and statistically significant. In this context, Krasniqi and Desai (2016) found innovation as a key factor that positively influences high-growth firms operating in transition economies. Calabrese et al. (2013) studied the relationship between types of innovations on firm performance in the context of Italian firms. They found a positive impact of innovation drivers on knowledge of grants and funding opportunities, network, and innovation efforts. On the other hand, innovation efforts and innovation protection affect the positive economic performance of the firm.

Bockova and Zizlavsky (2016) study the innovation and financial performance of a company in the context of the Czech manufacturing industry. Their analysis revealed that the long-term financial performance of investigated companies is closely linked to their investment into innovation. Ivanová and Kordoš (2017) conducted a study on innovation policy of SMEs in Slovakia in the context of European Union innovation policy. Surprisingly, they found no effect of the type of innovation policy on firms, so there is no statistically significant difference between investing in different types of innovation. Also, enterprises do not prefer individual financial sources on equivalent bases. Besides, they concluded that the type of innovation is not dependent on the size of an enterprise.

Žižlavsky (2016) focused in his research on the measurement of innovation performance, the degree and the methods of its implementation in the Czech business environment. According to the author, there is a tendency to neglect an essential area of research and development for the future existence of companies and increase their competitiveness. The author states that many businesses still do not measure the performance of innovation, although innovation is the engine of growth in the company. Only a few companies have a capable system in place to measure complex innovation performance. Large enterprises benefit from better innovations. The advantage of SMEs in innovation processes is their flexibility, more efficient use of innovative inputs due to individual entrepreneurial abilities, and greater flexibility in production processes. Czech manufacturing companies show 77\% (in 2014) irregularly and randomly innovated processes as a result of intuitive and immediate decision against negative development, respectively as an immediate reflection on the change in an external business environment. Only one-quarter of Czech businesses in 2014 implemented innovative processes as a standard part of their business activities, while systematically managing them. In Czech SMEs in 2014, companies most often invested $5 \%$ of their annual budget in innovation processes.

\section{AIM, METHODOLOGY AND DATA}

The paper's aim was to examine the dependence of the quality of the business environment on defined technological factors (availability of human capital and research and development infrastructure). Part of its goal was the comparison of the defined factors between the Czech Republic (CR) and the Slovak Republic (SR). 
In connection with the stated research goal, a questionnaire survey was conducted among businesses operating in the SMEs segment. Through this research, 312 companies were surveyed in the Czech Republic and 329 companies in the Slovak Republic. Data collection took place in 2018. The random selection method based on the mathematical function "Randbetween" was used to select SMEs from "Albertina", the Czech Republic's business database. Slovak companies were randomly selected from the "Cribis" database of companies, organisations, and self-employed. Subsequently, SMEs were addressed via an email requesting to fulfil out an online questionnaire. The questionnaire was intended for the owners of the companies or the top managers of these companies (hereinafter referred to as "entrepreneurs").

The response rate in the Czech Republic was approx. 4\% (the number of addressed entrepreneurs was more than 7800). The number of addressed businesses in the Slovak Republic was more than 9400. The response rate of completed questionnaires was approx. 3.5\%.

The structure of respondents in the Czech Republic (312 entrepreneurs) based the region of residence: Zlín region: 49 entrepreneurs, Usti region: 27 entrepreneurs, Central Bohemian region: 14 entrepreneurs, Plzeň region: 22 entrepreneurs, Pardubice region: 17 entrepreneurs, Olomouc region: 26 entrepreneurs, Moravian-Silesian region: 17 entrepreneurs, Liberec region: 28 entrepreneurs, Hradec Králové region: 17 entrepreneurs, Region Vysočina: 25 entrepreneurs, Karlovy Vary region: 15 entrepreneurs, South Moravian region: 22 entrepreneurs, South Bohemian region: 16 entrepreneurs, Capital city Prague: 17 entrepreneurs. Business sector: Services: 109 entrepreneurs, Commerce: 73 entrepreneurs, Production: 53 entrepreneurs, Construction: 29 entrepreneurs, Agriculture: 9 entrepreneurs, Transport: 19 entrepreneurs, Other: 23 entrepreneurs. The length of operating a business: 56 entrepreneurs $1-5$ years, 48 entrepreneurs 5 - 10 years, 208 entrepreneurs more than 10 years. Size: 258 micro-enterprises (up to 10 employees), 43 small enterprises (up to 50 employees), 11 medium enterprises (up to 250 employees). Highest education: 50 high school without a final exam, 135 high school with final exam, 127 higher education. Gender: 236 men, 76 women.

The structure of respondents in the Slovak Republic (329 entrepreneurs based on the region of residence: Prešov region: 76 entrepreneurs, Košice region: 75 entrepreneurs, Bratislava region: 56 entrepreneurs, Banská Bystrica region: 30 entrepreneurs, Žilina region: 28 entrepreneurs, Trnava region: 27 entrepreneurs, Trenčín region: 20 entrepreneurs, Nitra region: 17 entrepreneurs. Business sector: Services: 122 entrepreneurs, Commerce: 69 entrepreneurs, Production: 51 entrepreneurs, Construction: 39 entrepreneurs, Agriculture: 20 entrepreneurs, Transport: 11 entrepreneurs, Other: 17 entrepreneurs. The length of operating a business: 104 entrepreneurs $1-5$ years, 78 entrepreneurs $5-10$ years, 147 entrepreneurs more than 10 years. Size: 234 micro-enterprises (up to 10 employees), 71 small enterprises (up to 50 employees), 24 medium enterprises (do 250 employees). Highest education: 10 high school without final exam, 95 high school with final exam, 224 higher education. Gender: 251 men, 78 women.

Different technological factors were defined, in line with the definition by Conorto et al. (2014) through the following statements, which at the same time represent factors influencing the quality of the business environment in the SME segment. Individual factors were randomly assigned to the questionnaire to reach the highest level of objective responses.

In developing this paper, three scientific hypotheses were established:

H1: The availability and quality of human capital significantly influences the quality of the business environment.

H2: Research and development infrastructure has a significant impact on the quality of the business environment.

To evaluate the formulated hypotheses, the statistical regression analysis method was applied. The chosen method can be applied because all qualitative responses of entrepreneurs were transformed according to the Likert scale into quantitative data. The objective of the regression analysis is not to predict the future, but to quantify individual factors and subsequently verify their statistical significance for the quality of the business environment in selected countries. The linearity assumption was verified 
by a graphical analysis (with scatter plot). Its purpose is to show the presence of non-linear pairs between the dependent variable (QBE) and selected independent variables (factors: TF1, TF2, TF11..., TF24). The assumption of the normal distribution of the variables (factors and indicators) was verified as follows: Calculation of descriptive characteristics (skewness and kurtosis for each variable) and Zscore calculation of these descriptive characteristics. If the resulting $Z$-score values were in the range of values from -2 to 2 , then the assertion is that the variable meets the assumption of normal distribution. The verification of homoscedasticity was performed using the Bartlet test. By correlation matrix with correlation analysis, the pairwise variability between the variables was determined. Using t-tests, the statistical significance of the independent variable was verified (Factor - TF1, TF2 or TF11..., TF24) in the suggested regression model. Authors have designed regression models in a general shape (for each country) as follows:

Model 1: $\quad Q B E=\beta_{0}+\beta_{\mathrm{TF} 11} \times \mathrm{TF} 11+\beta_{\mathrm{TF} 12} \times \mathrm{TF} 12+\beta_{\mathrm{TF} 13} \times \mathrm{TF} 13+\beta_{\mathrm{TF} 14} \times \mathrm{TF} 14+e_{\dot{\nu}}$

Model 2: $\quad Q B E=\beta_{0}+\beta_{T F 21} \times T F 21+\beta_{T F 22} \times T F 22+\beta_{T F 23} \times T F 23+\beta_{T F 24} \times T F 24+e_{\text {, }}$

Model 3: $\quad Q B E=\beta_{0}+\beta_{T F 1} \times T F 1+\beta_{T F 2} \times T F 2+e_{i}$

where:

QBE - dependant value, $\beta_{0}$ - constant; $\beta_{T F 11, \ldots,} \beta_{T F 24,} \beta_{T F 1}, \beta_{T F 2}$ - coefficients of independent variables (TF1, TF2, TF11, ..., TF24); TF1 a TF2 - technological factors, TF11, ..., TF24 - indicators of technological factors; $e_{i}-$ random component.

The significance of the obtained regression models is verified by regression characteristics such as the coefficient of determination, the adjusted coefficient of determination, the Student's test, the multiple coefficients of correlation, the residual standard deviation, and the F-ratio. The presence of multicollinearity in regression models is verified by the variance inflation factor (VIF). If the VIF value of the test is higher than 5 , then the multicollinearity negatively influences the significance of the regression model. If regression coefficients of independent variables in regression models get positive, then the results indicate a positive impact on the quality of the business environment in the country. Due to the complexity of the above mentioned mathematical statistics, all of these tests are performed in the statistical data analysis software - IBM SPSS Statistics.

\section{RESULTS AND DISCUSSION}

The assumption of linearity and homoskedasticity is met for all variables. The assumption of normal distribution is not met for the variables (CR: TF12, TF21 and SR: TF11, TF14, TF21). Due to a large number of addressed entrepreneurs (more than 100) in both countries, it is possible to further test the indicators in another statistical analysis.

The following table (Table 1) summarises the pair correlation coefficients between dependent and independent variables for Model 1, Model 2 and Model 3.

Table 1 Correlation matrices between variables by selected countries

\begin{tabular}{|c|c|c|c|c|c|c|c|c|c|c|c|}
\hline \multicolumn{9}{|c|}{ Czech Republic } & \multicolumn{6}{c|}{ Slovak Republic } \\
\hline & QBE & TF11 & TF12 & TF13 & TF14 & & QBE & TF11 & TF12 & TF13 & TF14 \\
\hline QBE & 1 & & & & & QBE & 1 & & & & \\
\hline TF11 & 0,2205 & 1 & & & & TF11 & 0,2494 & 1 & & & \\
\hline TF12 & 0,1456 & 0,6059 & 1 & & & TF12 & 0,3243 & 0,6009 & 1 & & \\
\hline TF13 & 0,2775 & 0,4581 & 0,4620 & 1 & & TF13 & 0,2751 & 0,3402 & 0,3730 & 1 & \\
\hline TF14 & 0,2183 & 0,3049 & 0,3303 & 0,2979 & 1 & TF14 & 0,2438 & 0,3825 & 0,4172 & 0,5162 & 1 \\
\hline & QBE & TF21 & TF22 & TF23 & TF4 & & QBE & TF21 & TF22 & TF23 & TF4 \\
\hline QBE & 1 & & & & & QBE & 1 & & & & \\
\hline TF21 & 0,1917 & 1 & & & & TF21 & 0,2249 & 1 & & & \\
\hline TF22 & 0,2228 & 0,4623 & 1 & & & TF22 & 0,3130 & 0,5439 & 1 & & \\
\hline
\end{tabular}




\begin{tabular}{|c|c|c|c|c|c|c|c|c|c|c|c|}
\hline TF23 & 0,2085 & 0,2227 & 0,2719 & 1 & & TF23 & 0,3000 & 0,2867 & 0,3775 & 1 & \\
\hline TF24 & 0,2045 & 0,3835 & 0,3318 & 0,1648 & 1 & TF24 & 0,2047 & 0,2779 & 0,3870 & 0,3460 & 1 \\
\hline & QBE & TF1 & TF2 & & QBE & \multicolumn{2}{|c|}{ TF1 } & TF2 \\
\hline QBE & 1 & & & QBE & 1 & & \\
\hline TF1 & 0.2895 & 1 & & TF1 & 0.3578 & 1 & \\
\hline TF2 & 0.2984 & 0.3300 & & 1 & TF2 & 0.3599 & 0.4464 & 1 \\
\hline
\end{tabular}

(Source: own calculation)

The results (Table 1) show weak and moderate dependencies between the quality of the business environment and selected indicators of technological factors.

Despite the positive result of the correlation analysis between variables, the regression modelling is approached. Table 2 (Model 1), Table 3 (Model 2) and Table 4 (Model 3) summarise the basic regression characteristics and regression parameter estimates, and verify their statistical significance and the relevance of regression models.

Table 2 Verification of the statistical significance of the indicator "Availability and quality of human capital"

\begin{tabular}{|c|c|c|c|c|c|c|c|c|c|}
\hline \multicolumn{5}{|c|}{ Czech Republic } & \multicolumn{5}{|c|}{ Slovak Republic } \\
\hline \multicolumn{10}{|c|}{ Least squares multiple regression } \\
\hline \multicolumn{4}{|l|}{$\overline{\mathrm{R}^{2}}$} & 0.1066 & \multicolumn{4}{|c|}{$\mathrm{R}^{2}$} & 0.1369 \\
\hline \multicolumn{4}{|c|}{ Adjusted $\mathrm{R}^{2}$} & 0.0949 & \multicolumn{4}{|c|}{ Adjusted $\mathrm{R}^{2}$} & 0.1263 \\
\hline \multicolumn{4}{|c|}{ Multiple correlation coefficient } & 0.3265 & \multicolumn{4}{|c|}{ Multiple correlation coefficient } & 0.3701 \\
\hline \multicolumn{4}{|c|}{ Residual standard deviation } & 0.5301 & \multicolumn{4}{|c|}{ Residual standard deviation } & 0.5299 \\
\hline \multicolumn{10}{|c|}{ Regression equation } \\
\hline $\mathrm{P}$ & Coefficient & Std. Error & t-Stat & p-value & $\mathrm{P}$ & Coefficient & Std. Error & t-Stat & p-value \\
\hline Const & & & & & Const & & & & \\
\hline TF11 & 0.1395 & 0.0782 & 1.7845 & 0.0753 & TF11 & 0.0469 & 0.0668 & 0.7020 & 0.4832 \\
\hline TF12 & -0.0841 & 0.0791 & -1.0635 & 0.2884 & TF12 & 0.1255 & 0.0701 & 3.2163 & 0.0014 \\
\hline TF13 & 0.2368 & 0.0707 & 3.3470 & 0.0009 & TF13 & 0.1474 & 0.0615 & 2.3956 & 0.0172 \\
\hline TF14 & 0.1434 & 0.0591 & 2.4269 & 0.0158 & TF14 & 0.0555 & 0.0593 & 0.9367 & 0.3496 \\
\hline \multicolumn{10}{|c|}{ Analysis of variance } \\
\hline \multicolumn{4}{|l|}{ F-test } & 9.158 & \multicolumn{4}{|c|}{ F-test } & 12.852 \\
\hline \multicolumn{4}{|c|}{ P-value } & $5.31 \mathrm{E}-7$ & \multicolumn{4}{|c|}{ P-value } & $1.01 \mathrm{E}-9$ \\
\hline
\end{tabular}

${ }^{*} \mathrm{R}^{2}$ : coefficient of determination; $\alpha=0.05$ ( $\alpha$ - significance level).

(Source: own calculation)

A statistically significant indicator of QBE in both countries is that universities are preparing highquality graduates who are fit for use in the corporate sector (TF13). Another important factor in the Czech Republic is that there are enough skilled workers in the labour market that are fit for use in the corporate sector, and in the Slovak Republic, secondary schools prepare enough high-quality graduates for the companies' needs.

Table 3 Verification of the statistical significance of the indicator "Infrastructure for research and development"

\begin{tabular}{|l|l|l|c|}
\hline \multicolumn{3}{|c|}{ Czech Republic } & \multicolumn{3}{c|}{ Slovak Republic } \\
\hline \multicolumn{3}{|c|}{ Least squares multiple regression } & 0.1404 \\
\hline $\mathrm{R}^{2}$ & 0.0918 & $\mathrm{R}^{2}$ & 0.1298 \\
\hline Adjusted $\mathrm{R}^{2}$ & 0.0800 & Adjusted $\mathrm{R}^{2}$ & \\
\hline
\end{tabular}




\begin{tabular}{|c|c|c|c|c|c|c|c|c|c|}
\hline \multicolumn{4}{|c|}{ Multiple correlation coefficient } & 0.3030 & \multicolumn{4}{|c|}{ Multiple correlation coefficient } & 0.3747 \\
\hline \multicolumn{4}{|c|}{ Residual standard deviation } & 0.9610 & Residu & al standard d & viation & & 0.9280 \\
\hline \multicolumn{10}{|c|}{ Regression equation } \\
\hline $\mathrm{P}$ & Coefficient & Std. Error & t-Stat & $\mathrm{p}$-value & $\mathrm{P}$ & Coefficient & Std. Error & t-Stat & p-value \\
\hline Const & & & & & Const & & & & \\
\hline TF21 & 0.0767 & 0.0815 & 0.9400 & 0.3479 & TF21 & 0.0553 & 0.0679 & 0.8147 & 0.4158 \\
\hline TF22 & 0.1475 & 0.0806 & 1.8310 & 0.0681 & TF22 & 0.1981 & 0.0674 & 2.9395 & 0.0035 \\
\hline TF23 & 0.1871 & 0.0741 & 2.5247 & 0.0121 & TF23 & 0.2073 & 0.0607 & 3.4139 & 0.0007 \\
\hline TF24 & 0.1540 & 0.0777 & 1.9822 & 0.0483 & TF24 & 0.0518 & 0.0619 & 0.8371 & 0.4032 \\
\hline \multicolumn{10}{|c|}{ Analysis of variance } \\
\hline \multicolumn{4}{|c|}{ F-test } & 7.757 & \multicolumn{4}{|c|}{ F-test } & 13.231 \\
\hline \multicolumn{4}{|c|}{ P-value } & $5.75 \mathrm{E}-6$ & \multicolumn{4}{|c|}{ P-value } & $5.38 \mathrm{E}-10$ \\
\hline
\end{tabular}

${ }^{*} \mathrm{R}^{2}$ : coefficient of determination; $\alpha=0.05$ ( $\alpha$ - significance level).

(Source: own calculation)

A statistically significant indicator of QBE in both countries is that research and development results help entrepreneurs (TF23). Another important factor in the Czech Republic is that the support of research and development by the state has an upward trend (TF24), and in the Slovak Republic, the factor that the support of research and development by the state is good (TF22).

\section{Table 4 Verification of the statistical significance of the indicator "Quality of the business environment"}

\begin{tabular}{|c|c|c|c|c|c|c|c|c|c|}
\hline \multicolumn{5}{|c|}{ Czech Republic } & \multicolumn{5}{|c|}{ Slovak Republic } \\
\hline \multicolumn{10}{|c|}{ Least squares multiple regression } \\
\hline \multicolumn{4}{|l|}{$\mathrm{R}^{2}$} & 0.1300 & \multicolumn{4}{|c|}{$\mathrm{R}^{2}$} & 0.1781 \\
\hline \multicolumn{4}{|c|}{ Adjusted $\mathrm{R}^{2}$} & 0.1244 & \multicolumn{4}{|c|}{ Adjusted $\mathrm{R}^{2}$} & 0.1731 \\
\hline \multicolumn{4}{|c|}{ Multiple correlation coefficient } & 0.3606 & \multicolumn{4}{|c|}{ Multiple correlation coefficient } & 0.4220 \\
\hline \multicolumn{4}{|c|}{ Residual standard deviation } & 0.9375 & \multicolumn{4}{|c|}{ Residual standard deviation } & 0.5047 \\
\hline \multicolumn{10}{|c|}{ Regression equation } \\
\hline $\mathrm{P}$ & Coefficient & Std. Error & $\mathrm{t}-\mathrm{Stat}$ & p-value & $\mathrm{P}$ & Coefficient & Std. Error & $\mathrm{t}-$ Stat & p-value \\
\hline Const & & & & & Const & & & & \\
\hline TF1 & 0.0782 & 0.0205 & 3.8132 & 0.0002 & TF1 & 0.0805 & 0.0183 & 4.3896 & 0.0000 \\
\hline TF2 & 0.1054 & 0.0260 & 4.0508 & 0.0001 & TF2 & 0.0914 & 0.0205 & 4.4545 & 0.0000 \\
\hline \multicolumn{10}{|c|}{ Analysis of variance } \\
\hline \multirow{2}{*}{\multicolumn{4}{|c|}{$\frac{\text { F-test }}{\text { P-value }}$}} & 23.088 & \multicolumn{4}{|c|}{ F-test } & 35.322 \\
\hline & & & & $4.51 \mathrm{E}-10$ & \multicolumn{4}{|c|}{ P-value } & $1.3 \mathrm{E}-14$ \\
\hline
\end{tabular}

${ }^{*} \mathrm{R}^{2}$ : coefficient of determination; $\alpha=0.05$ ( $\alpha$ - significance level).

(Source: own calculation)

The results (Table 2, Table 3, and Table 4) show that all regression models in both countries are statistically significant because the F-ratio values are below the set level of significance. Negative phenomena such as multicollinearity are not present in the regression models. The values of the adjusted determination coefficients are low (ranging from 0.8 to 17.31), thus indicate that the selected factors explain a maximum of $17.3 \%$ of the variability of entrepreneurs' responses to the quality of the business environment in the country.

The regression models for each country acquire the following shapes: 
- Czech Republic:

Model 1: $\quad Q B E=0.2368 \times T F 13+0.1434 \times T F 14$,

Model 2: $\quad Q B E=0.1871 \times \mathrm{TF} 23+0.1540 \times \mathrm{TF} 24$,

Model 3: $\quad Q B E=0.0782 \times T F 1+0.1054 \times T F 2$,

- Slovak Republic:

Model 1: $\quad Q B E=0.1255 \times T F 12+0.1474 \times T F 13$,

Model 2: $\quad Q B E=0.1981 \times T F 22+0.2073 \times T F 23$,

Model 3: $\quad Q B E=0.0805 \times T F 1+0.0914 \times T F 2$,

All regression coefficients of both indicators and factors are positive, i.e. have a positive impact on the quality of the business environment in the selected country. Based on the above calculations, hypothesis $\mathrm{H} 1$ and hypothesis $\mathrm{H} 2$ are accepted.

\section{CONCLUSION}

The paper's aim was to examine the dependence of the quality of the business environment on defined technological factors (availability of human capital and research and development infrastructure). Part of its goal was the comparison of the defined factors between the Czech Republic (CR) and the Slovak Republic (SR).

Formulated technological factors (research and development infrastructure, availability and quality of human capital) positively affect the business environment in both countries. Research and development infrastructure has a stronger impact on the quality of the business environment than the availability and quality of human capital in both countries. The most important indicator that positively influences the quality of the business environment in the Czech Republic is that universities are preparing high-quality graduates who are fit for use in the corporate sector. The most important indicator that positively influences the quality of the business environment in the Slovak Republic is that the research and development results help entrepreneurs. On the other hand, it is necessary to take into account that the quality of the business environment is also influenced by other factors not mentioned in this case study.

The research has some limits, but it has brought interesting findings and possible inspiration for further research focused on the quality of SMEs' business environment.

\section{REFERENCES}

Acs, Z. J., Braunerhjelm, P., Audretsch, D. B., \& Carlsson, B. (2009). The knowledge spillover theory of entrepreneurship. Small Business Economics, 32(1), pp. 15-30. https://doi.org/10.1007/s11187$\underline{008-9157-3}$

Belás, J., Dvorský, J., Kubálek, J., \& Smrčka, L. (2018). Important factors of financial risk in the SME segment. Journal of International Studies, 11(1), pp. 80-92. doi:10.14254/2071-8330.2018/11-1/6

Belas, J., Kljucnikov, A., Vojtovic, S., \& Sobekova-Májkova, M. (2015). Approach of the SME Entrepreneurs to Financial Risk Management in Relation to Gender and Level of Education. Economics and Sociology, Vol. 8, No 4, pp. 32-42.

Bergmann, H., Hundt, C., Sternberg, R. (2016). What makes student entrepreneurs? On the relevance (and irrelevance) of the university and the regional context for student start-ups. Small Bus Econ 47, 53.

Bockova, N., \& Zizlavsky, O. (2016). The Innovation and Financial Performance of a Company: A Study from Czech Manufacturing Industry. Transformations in Business \& Economics, 15(3), pp. 156175. 
Botlikova, M., Botlik, J. (2014). Analysis of Business Environment. Sborník prǐspěvkiu XV II. mezinárodní kolokvium o regionálních védách, Hustopeče 18.-20. 6. 2014.

Bunoa, M., Nadanyiova, M., \& Hraskova, D. (2015). The comparison of the quality of business environment in the countries of Visegrad group. Procedia Economics and Finance 26, pp. 423-430.

Calabrese, A., Campisi, D., Capece, G., Costa, R., \& Di Pillo, F. (2013). Competiveness and Innovation in High-tech Companies: An Application to the Italian Biotech and Aerospace Industries. International Journal of Engineering Business Management, 5, 40. https://doi.org/10.5772/56755

Conorto, R. a kol. (2014). Analýza, monitor kvality podnikatel'kébo prostredia v SR a konkurencieschopnost' ekonomiky. Bratislava: Centrum vzdelávania MPSVR SR.

Czarniewski, S. (2016). Small and Medium-Sized Enterprises in the Context of Innovation and Entrepreneurship in the Economy. Polish Journal of Management Studies, Vol. 13, No. 1, pp. 30-39.

Dobeš, K., Kot, S., Kramoliš, J., \& Sopková, G. (2017). The Perception of Governmental Support in The Context of Competitiveness of SMEs in the Czech Republic. Journal of Competitiveness, Vol. 9, Issue 3, pp. 34-50. DOI: 10.7441/joc.2017.03.03

Dubravska, M., Mura, L., Kotulic, R., \& Novotny, J. (2015). Internationalization of Entrepreneurship Motivating Factors: Case Study of the Slovak Republic. Acta Polytechnica Hungarica, 12 (5), pp. $121-$ 133.

Fetisovová, E. a kol. (2012). Aktuálne problémy financii malých a stredných podnikov. Bratislava: Ekonóm.

González-Pernía, J. L., Jung, A., \& Peña, I. (2015). Innovation-driven entrepreneurship in developing economies. Entrepreneurship \& Regional Development, 27(9-10), pp. 555-573. https://doi.org/10.1080/08985626.2015.1075602

Hashi, I., \& Krasniqi, B. A. (2011). Entrepreneurship and SME growth: evidence from advanced and laggard transition economies. International Journal of Entrepreneurial Behavior \& Research, 17(5), pp. 456-487. https://doi.org/10.1108/13552551111158817

Hudáková, M., Schönfeld, J., Dvorský, J., \& Lusková, M. (2017). The market risk analysis and methodology of its more effective management in SMEs in the Slovak Republic. Montenegrin Journal of Economics, 13(2), pp. 151-161. doi:10.14254/1800-5845/2017.13-2.10

Hudakova, M., Dvorský, J. (2018). Assessing the risks and their sources in dependence on the rate of implementing the risk management process in the SMEs. Equilibrium. Quarterly Journal of Economics and Economic Policy, 13(3). doi: 10.24136/eq.2018.027

Chládková, H. (2015). Selected approaches to the business environment evaluation. Acta Universitatis Agriculturae et Silviculturae Mendelianae Brunensis, Volume 63, Number 2, pp. 513-523. http://dx.doi.org/10.11118/actaun201563020515

Irwin, D., Scott, J. M. (2010). Barriers Faced by SMEs in Raising Bank Finance. International Journal of Entrepreneurial Behavior and Research, 16(9).

Ivanová, E., \& Kordoš, M. (2017). Innovation policy of SMEs in Slovakia in the context of European Union innovation policy. Marketing and Management of Innovations, (3), pp. 213-225. https://doi.org/10.21272/mmi.2017.3-20

Jones, P., Miller, C., Jones, A., Packham, G., Zbierowski, P. (2011). Attitudes and motivations of Polish students towards entrepreneurial activity. Education + Training, Vol. 53(5), pp. 416-432.

Ključnikov, A., Popesko, B. (2017). Export and its Financing in The SME Segment. Case Study From Slovakia. Journal of Competitiveness, Vol. 9, Issue 1, pp. 20-35. DOI: 10.7441/joc.2017.01.02

Korcsmáros, E., Mura, L., Simonová, M. (2017). Identification of small and medium-sized enterprises development in Slovakia. Journal of Applied Economic Sciences, Vol. 12, No. 6, pp. 1702-1712.

Koval'ová, M., Hvolková, L., Klement, L., Klementová, V. (2018). Innovation strategies in the Slovak enterprises. Acta Oeconomica Universitatis Selye 7 (1), pp. 79 - 89.

Kozubíková, L., Homolka, L., Kristalas, D. (2017). The Effect of Business Environment and Entrepreneurs' Gender on Perception of Financial Risk in The SMEs Sector. Journal of Competitiveness, Vol. 9, Issue 1, pp. 36-50. DOI: 10.7441/joc.2017.01.03

Krasniqi, B. A., \& Desai, S. (2016). Institutional drivers of high-growth firms: country-level evidence from 26 transition economies. Small Business Economics, 47(4), pp. 1075-1094. https://doi.org/10.1007/s11187-016-9736-7 
Lafuente, E. M., Vaillant, Y. (2013). Age Driven Influence of Role-Models on Entrepreneurship in a Transition Economy. Journal of Small Business and Enterprise Development, Vol. 20, No 1, s.181-203.

Lazányi, K., Virglerová, Z., Dvorský, J., \& Dapkus, R. (2017). An analysis of factors related to "taking risks", according to selected socio-demographic factors. Acta Polytecbnica Hungarica, 14(7), pp. 3550. doi:10.12700/APH.14.7.2017.7.3

Millian, J. M., Congregado, E., Roman, C., Van Praag, M., Van Stel, A. (2014). The value of an educated population for an individual's entrepreneurship success. Journal of Business Venturing, 29, pp. 312632.

Naude, W., Gries, T., Wood, E., Meintjiess, A. (2008). Regional determinants of Entrepreneurial Startups in a Developing Country. Entrepreneurship and Regional Development, Vol. 20, No 2, pp.111124.

Oehler, A., Hofer, A., Schalkowski, H. (2015). Entrepreneurial education and knowledge: empirical evidence on a sample of German undergraduate students. J Technol Transf 40, pp. 536-557.

Popescu, C. C., Bostan, I., Robu, I. B., , Maxim, A., \& Diaconu, L. (2016). An Analysis of the Determinants of Entrepreneurial Intentions among Students: A Romanian Case Study. Sustainability, 8, 771.

Rauch, A., Rijsdijk, S. A. (2013). The effects of general and specific human capital on long-term growth and failure of newly founded businesses. Entrepreneurship Theory and Practice, 37(4), pp. 923-941.

Tredevi, R. (2016). Does university play significant role in shaping entrepreneurial intention? A crosscountry comparative study, Journal of Small Business and Enterprise Development, Vol. 23(1), pp. 790 811.

Van der Sluis, J., Van Praag, M. (2008). Education and Entrepreneurship Selection and Performance: A Review of the Empirical Literature. Journal of Economic Surveys, Vol. 22, No 5, pp.795-841.

Velez, C.M. (2009). The Probability of Transition to Entrepreneurship Revisited: Wealth, Education and Age. Annals of Finance, Vol. 5, No 3, pp.421-441.

Wruuck, P. (2015). The business environment in the eurozone. Deutsche Bank AG Deutsche Bank Research Frankfurt am Main Germany. Available at: https://www.dbresearch.com/PROD/DBR INTERNET EN-PROD/ PROD $000000 \quad 00$ 00379559/The business environment in the eurozone\%3A Why it i.pdf

Žizlavsky, O. (2016). Innovation performance measurement: research into Czech business practice. Economic Research-Ekonomska Istrą̌rivanja, 29(1), pp. 816-838. 